\title{
A healthy eating plan for employees engaged in oil and gas exploration and production in the Far North
}

\author{
Andrey Vekovtsev, Elena Vovk, Valery Poznyakovsky, Boisjoni Tokhiriyon*, and \\ Valentina Lapina \\ Ural State University of Economics, Ulitsa 8 Marta, 62/45, 620144 Ekaterinburg, Russia
}

\begin{abstract}
Proper nutrition is undoubtedly one of the most important factors of good health. Currently, the priority field of study for the Russian nutritionists is the development of well-balanced nutrition plans which can help to prevent or alleviate the most common medical conditions and work-related diseases. Extensive research has been carried out for the stateled program for the Development of Hydrocarbon Resources in the Northern Regions of Russia, including the Far North, where the huge oil and gas fields are located, and the specialists of Art-Life scientific production association have developed a healthy eating plan to help people working in the Far North maintain general well-being.
\end{abstract}

\section{Introduction}

The extreme weather conditions of the Far North are well-known, and because of the climate-related health threats this climatic zone in Russia is regarded as highly unfavourable for living. Employees who are brought to the Far North from other Russian regions experience an extended strain arising from both extreme cold and difficult work conditions. Research has demonstrated a phospholipids deficiency which leads to the exhaustion of the body's compensatory mechanisms, occupational diseases and pathological processes. Therefore, in order to improve the living conditions, it is primarily important to develop well-balanced diets with all the necessary micronutrients and macronutrients included. At the same time, the costs should also be taken into the account, as a very limited range of foods can be produced in the Far North; most foodstuffs have to be delivered from elsewhere [1,6-15].

In addition to the unfavourable weather conditions, employees engaged in oil and gas exploration and production suffer from chemical, physical and other harmful factors of the industrial environment. These negative factors disrupt metabolism and the immune system, and consequently affect general well-being, work performance and life expectancy. Therefore, there are a number of factors to be taken into account when developing diets aimed at replenishing nutrients and improving the general well-being of people living and working in the Far North [1-5].

\footnotetext{
*Corresponding author: tohiriyoni@gmail.com
} 


\section{Materials and methods}

The materials used are natural raw materials of plant and animal origin, semi-finished products, laboratory and experimental samples of the food supplement. Standardized and modified test methods have been used to assess the quality characteristics of the product

\section{Results and discussion}

Although, nowadays Russian authorities are looking into ways to promote healthy dietary practices, the recent data on food consumption indicate the overall decrease in the consumption of fruit and vegetables, meat, dairy and fish products as well as the increase in sugar consumption. These changes inevitably result in different noncommunicable diseases and conditions. Comparing the nutritional guidelines for different Russian regions, we can notice certain differences. The Nutritional guidelines for the regions of the temperate climate zone and the Far North developed by the Federal State Budgetary Scientific Institution - the Institute of Nutrition, Biotechnology and Food Safety are presented in Table 1 .

Table 1. Daily Nutritional Guidelines

\begin{tabular}{|l|c|c|}
\hline Foods & $\begin{array}{l}\text { Temperate climate zone } \\
\text { (gram) }\end{array}$ & Far North (gram) \\
\hline Whole grains & 64.0 & 345.2 \\
\hline Fruit and vegetables & 302.0 & 315.0 \\
\hline potatoes & 275.0 & 300.0 \\
\hline Meat & 167.0 & 250.1 \\
\hline Dairy & 486.0 & 1747.1 \\
\hline Fats & 40.0 & 85.0 \\
\hline Sugar & 86.0 & 115.0 \\
\hline Fish & 51.0 & 54.8 \\
\hline
\end{tabular}

As can be seen from the table, the differences are significant, as energy intake has to be in balance with energy expenditure. Although other individual characteristics like gender, lifestyle, and physical activity have to be considered, climate is still a very important one. Thus, the energy intake for people living in the Far North is one and a half times as large as the energy intake for people living in the temperate climate zone.

Because of the chronic cold exposure people working and living in the Far North have to adjust to cold temperatures, but cold acclimatization takes time and while people are adapting to cold, iron and fluorine deficiencies cause iron deficiency anaemia, increased dental caries, hypovitaminosis and unsettle the immune system. For these reasons, foods fortified with minerals and vitamins have to be included in the diets of people in the Far North to help maintain healthy dietary practices.

One of the possible solutions, which can successfully cater for employees engaged in oil and gas exploration and production in the Far North, provide all the essential micronutrients and allow to develop healthy food environments, is the use of dietary supplements.

The specialists of Art-Life scientific production association have developed their healthy eating plan to help people working in the Far North maintain a healthy diet and prevent work-related diseases. The plan includes the following dietary supplements:

- Soft drinks concentrates (a vitamin fortified beverage with a choice of flavours) 
- $\quad$ Fruit and berry jelly drinks fortified with vitamins and calcium (a wide choice of flavours)

- Protein shakes with vitamins and amino acids

- Protein bars

In addition, Omega 3 dietary supplement is recommended to be consumed. The complex is a source of essential fatty acids, vitamin E, selenium, lipoic acid, and dihydroquercetin. The data on the healthy eating plan are presented in Table 2 and the recommended healthy eating plan is shown in Figure 1.

Table 2. The Proposed Healthy Eating Plan: Contents

\begin{tabular}{|c|c|c|c|c|}
\hline Drinks & $\begin{array}{l}\text { Recommended daily } \\
\text { amount } \\
\text { (prepared drink in } \mathrm{ml} \text { ) }\end{array}$ & \multicolumn{2}{|l|}{ Contents } & $\begin{array}{l}\text { \% RDI per } \\
\text { drink/bar }\end{array}$ \\
\hline \multirow{11}{*}{$\begin{array}{l}\text { Made from soft } \\
\text { drinks concentrate } \\
\text { fortified with } \\
\text { vitamins }\end{array}$} & \multirow[t]{11}{*}{200 (once a day) } & Energy value, kcal & 56.4 & 2.0 \\
\hline & & Carbohydrates, $\mathrm{g}$ & 10.51 & 3.0 \\
\hline & & Organic acids, g & 0.4 & - \\
\hline & & Vitamin A, mg & 0.5 & 62.5 \\
\hline & & Vitamin $\mathrm{C}, \mathrm{mg}$ & 100 & 167 \\
\hline & & Vitamin $\mathrm{B}_{1}, \mathrm{mg}$ & 1.1 & 79 \\
\hline & & Vitamin $\mathrm{B}_{2}, \mathrm{mg}$ & 1.1 & 69 \\
\hline & & Vitamin PP, mg & 10 & 56 \\
\hline & & Tannin, mg & 11.25 & 3.8 \\
\hline & & Caffeine, $\mathrm{mg}$ & 7.5 & 15 \\
\hline & & Silybin, $\mathrm{mg}$ & 30 & 100 \\
\hline \multirow{15}{*}{$\begin{array}{l}\text { Fruit and berry jelly } \\
\text { drinks fortified with } \\
\text { vitamins and } \\
\text { calcium }\end{array}$} & \multirow[t]{15}{*}{200 (once a day) } & Energy value, kcal & 49.05 & 2.0 \\
\hline & & Carbohydrates, $\mathrm{g}$ & 13.62 & 4.0 \\
\hline & & Organic acids, $\mathrm{g}$ & 174 & - \\
\hline & & Vitamin A, mg & 0.5 & 63 \\
\hline & & Vitamin E, mg & 15 & 150 \\
\hline & & Vitamin $\mathrm{B}_{1}, \mathrm{mg}$ & 1.9 & 136 \\
\hline & & Vitamin $B_{2}, \mathrm{mg}$ & 3.0 & 188 \\
\hline & & Vitamin $\mathrm{B}_{6}, \mathrm{mg}$ & 7.3 & 365 \\
\hline & & Vitamin PP, mg & 9.0 & 50 \\
\hline & & Vitamin $\mathrm{B}_{5}, \mathrm{mg}$ & 6.5 & 108 \\
\hline & & Vitamin $\mathrm{B}_{12}, \mathrm{mcg}$ & 6.5 & 650 \\
\hline & & Vitamin $\mathrm{B}_{9}, \mathrm{mg}$ & 0.6 & 300 \\
\hline & & Vitamin $\mathrm{H}, \mathrm{mcg}$ & 48 & 96 \\
\hline & & Vitamin $\mathrm{C}, \mathrm{mg}$ & 30 & 50 \\
\hline & & Calcium, mg & 130 & 13 \\
\hline \multirow{19}{*}{$\begin{array}{l}\text { Protein shakes with } \\
\text { vitamins and amino } \\
\text { acids }\end{array}$} & \multirow{19}{*}{$\begin{array}{c}100 \\
\text { (three times a day) }\end{array}$} & Energy value, kcal & 123 & 15 \\
\hline & & Proteins, $\mathrm{g}$ & 8.12 & 32 \\
\hline & & L-carnitine, $\mathrm{g}$ & 0.13 & 129 \\
\hline & & L-taurine, $\mathrm{g}$ & 0.13 & 99 \\
\hline & & Glutaminic acid, $\mathrm{g}$ & 1.20 & 26 \\
\hline & & Isoleucine, $\mathrm{g}$ & 0.39 & 58 \\
\hline & & Methionine + cystine, $\mathrm{g}$ & 0.42 & 70 \\
\hline & & Valine, $\mathrm{g}$ & 0.42 & 50 \\
\hline & & Tryptophan, g & 0.13 & 49 \\
\hline & & Phenylalanine + tyrosine, $\mathrm{g}$ & 0.62 & 42 \\
\hline & & Threonine, $\mathrm{g}$ & 0.33 & 41 \\
\hline & & Leucine, $g$ & 0.59 & 38 \\
\hline & & Lysine, $\mathrm{g}$ & 0.49 & 36 \\
\hline & & Arginine, $\mathrm{g}$ & 0.56 & 27 \\
\hline & & Proline, $\mathrm{g}$ & 0.41 & 27 \\
\hline & & Histidine, $\mathrm{g}$ & 0.18 & 26 \\
\hline & & Glycine, $\mathrm{g}$ & 0.26 & 22 \\
\hline & & Aspartic acid, g & 0.76 & 18 \\
\hline & & Alanin, $g$ & 0.34 & 15 \\
\hline
\end{tabular}


Table 2. Continued

\begin{tabular}{|c|c|c|c|c|}
\hline \multirow{18}{*}{\multicolumn{2}{|c|}{ 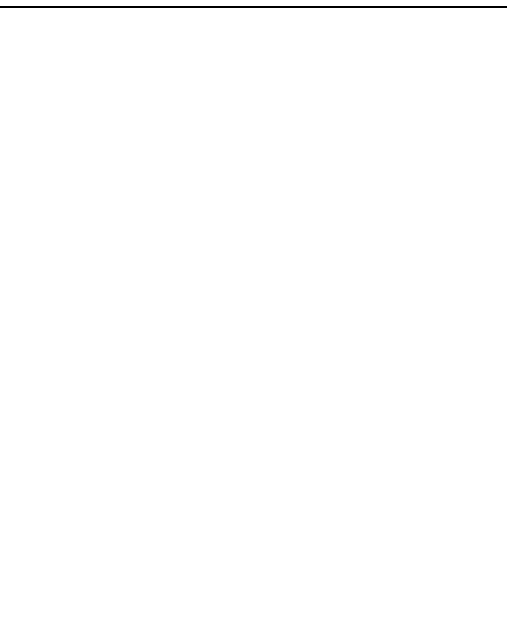 }} & Serine, $g$ & 0.36 & 13 \\
\hline & & Carbohydrates, $g$ & 12.2 & 10 \\
\hline & & Lactulose, g & 1.0 & 150 \\
\hline & & Dietary soluble fiber, $g$ & 0.265 & 40 \\
\hline & & Fats, $g$ & 4.65 & 17 \\
\hline & & $\begin{array}{l}\text { Medium chain triglycerides, } \\
\mathrm{g}\end{array}$ & 0.39 & - \\
\hline & & Vitamin $B_{1}, \mathrm{mg}$ & 0.31 & 22 \\
\hline & & Vitamin $\mathrm{B}_{2}, \mathrm{mg}$ & 0.37 & 23 \\
\hline & & Vitamin $\mathrm{B}_{3}, \mathrm{mg}$ & 3.67 & 20 \\
\hline & & Vitamin $\mathrm{B}_{5}, \mathrm{mg}$ & 0.92 & 15 \\
\hline & & Vitamin $\mathrm{B}_{6}, \mathrm{mg}$ & 0.37 & 19 \\
\hline & & Vitamin $\mathrm{B}_{9}, \mathrm{mg}$ & 0.074 & 37 \\
\hline & & Vitamin $\mathrm{B}_{12}, \mathrm{mg}$ & 0.83 & 83 \\
\hline & & Vitamin $\mathrm{C}, \mathrm{mg}$ & 12.8 & 21 \\
\hline & & Vitamin E, mg & 1.38 & 14 \\
\hline & & Calcium, mg & 144 & 15 \\
\hline & & Phosphorus, mg & 149 & 19 \\
\hline & & Iodine, mcg & 23.7 & 16 \\
\hline \multirow[t]{21}{*}{ Protein bars } & \multirow{21}{*}{1 bar (60 gram) } & Energy value, kcal & 173.45 & 7 \\
\hline & & Proteins, $g$ & 20.34 & 27 \\
\hline & & Fats, $g$ & 2.89 & 5 \\
\hline & & Carbohydrates, $\mathrm{g}$ & 16.52 & 5 \\
\hline & & Calcium, mg & 40.5 & 4 \\
\hline & & Phosphorus, mg & 33.75 & 4 \\
\hline & & Iodine, mcg & 6.75 & 5 \\
\hline & & Soluble dietary fiber, $g$ & 3.49 & 12 \\
\hline & & L-carnitine, $\mathrm{g}$ & 0.11 & 37 \\
\hline & & Caffeine, $\mathrm{mg}$ & 11 & 22 \\
\hline & & Vitamin $\mathrm{B}_{1}, \mathrm{mg}$ & 0.42 & 30 \\
\hline & & Vitamin $\mathrm{B}_{2}, \mathrm{mg}$ & 0.48 & 30 \\
\hline & & Vitamin $\mathrm{B}_{3}, \mathrm{mg}$ & 5.4 & 30 \\
\hline & & Vitamin $\mathrm{B}_{5}, \mathrm{mg}$ & 1.8 & 30 \\
\hline & & Vitamin $\mathrm{B}_{6}, \mathrm{mg}$ & 0.6 & 30 \\
\hline & & Vitamin $\mathrm{B}_{9}, \mathrm{mg}$ & 0.06 & 30 \\
\hline & & Vitamin $B_{12}, \mathrm{mcg}$ & 0.0003 & 30 \\
\hline & & Vitamin $C, m g$ & 18.0 & 30 \\
\hline & & Vitamin D, mcg & 1.5 & 30 \\
\hline & & Vitamin A, mg & 0.24 & 30 \\
\hline & & Vitamin E, mg & 3.0 & 30 \\
\hline \multirow[t]{7}{*}{ Omega 3 complex } & \multirow[t]{7}{*}{1 capsule } & Eicosapentaenoic acid & 90 & \multirow[t]{3}{*}{35} \\
\hline & & Docosahexaenoic acid & 60 & \\
\hline & & Alpha linolenic acid & 200 & \\
\hline & & Lipoic acid & 9.0 & 30 \\
\hline & & Dihydroquercetin & 7.5 & 30 \\
\hline & & Vitamin E & 3.0 & 30 \\
\hline & & Selenium & 0.01 & 15 \\
\hline
\end{tabular}

* Recommended daily intake in accordance with Technical regulations of the Eurasian Economic Union $022 / 2011$ 


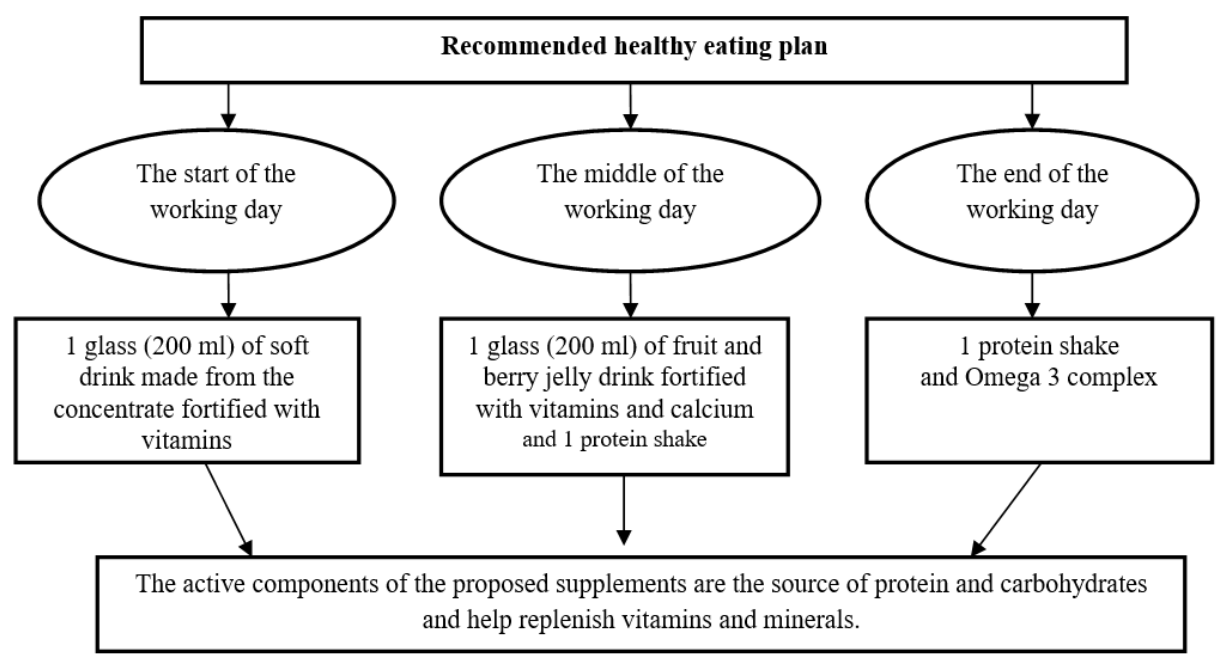

Fig. 1. Recommended healthy eating plan.

\section{Conclusion}

The proposed healthy eating plan helps counteract the effects of stress, improve digestion, and has a positive effect on gastric secretion. The active components improve liver function, regulate the viscosity and $\mathrm{pH}$ of blood and, thus, the heart rate and heart activity; strengthen metabolic processes, and increase efficiency. In addition, the active components make a favourable impact on the central nervous system, improving coordination of movements.

Vitamins perform catalytic functions and stimulate chemical reactions in the body. They assist in forming and functioning of enzymes, help absorb nutrients, enhance cell growth and overall strengthening of the body.

\section{References}

1. N.Kh. Amirov, Occupational medicine and industrial ecology, 4 (2003)

2. V.M. Akhmetov, Occupational medicine and industrial ecology, 5 (2002)

3. E.N. Belyaev, Nutrition issues, 3 (1996)

4. A.V. Shabrov, Biochemical basis of the action of food micronutrients (2003)

5. V.A. Tutelyan, Your food, 4 (2000)

6. B. Tokhiriyon, V. M. Poznyakovsky, S. Andrievskikh, Carpathian journal of food science and technology 12(1), 52-60 (2020)

7. B. Tokhiriyon, V. M. Poznyakovsky, N. M. Beliaev, International Journal of Pharmaceutical Research \& Allied Sciences, 8(1), 115-122 (2019)

8. B. Tokhiriyon, E. V. Vyalyh, V. M. Poznyakovsky, Innovative technology of natural raw materials processing and biologically active complexes with systemic effect development, International Scientific and Practical Conference "Digital agriculture development strategy" 167 (International Scientific and Practical, Ajman, 2019), 455458 (2019) 
9. A. A. Utebaeva, M. A. Burmasova, M. A. Sysoeva, Applied Chemistry and Biology, 6 (19), 100-109 (2016)

10. V. L. Fulgoni, D. R. Keast, R. L. Bailey, Journal of nutrition, 141, 1847-1854 (2011)

11. H. Knopf, G. Sarganas, D. Grams, Bundesgesundheitsblatt - Gesundheitsforschung Gesundheitsschutz, 62 (2019)

12. N. S. Karamnova, CardioSomatics, 8:1 (2017)

13. E. V. Averyanova, V. N. Khmelev, S. N. Tsyganok, V. A. Shakura, 18th International Conference of Young Specialists on Micro/Nanotechnologies and Electron Devices EDM 2017: Conference Proceedings, 255-259 (2017)

14. J. Sacco, V. Tarasuk, Procedia Food Science, 2, 203-210 (2013)

15. M. F. San Martin, G. V. Barbosa Canovas, B. G. Swanson, Critical Reviews in Food Science and Nutrition, 42, 627-645 (2002) 